\title{
THE COMPARISON OF THE POTENTIAL EFFECT OF CLIMATE CHANGE ON THE SEGMENT GROWTH OF FRAXINUS ORNUS, PINUS NIGRA AND AILANTHUS ALTISSIMA ON SHALLOW, CALCAREOUS SOILS
}

\author{
TrÁJJer, A..$^{1,2 *}$ - HAMMER, T. ${ }^{1}$ - BEDE-FAZEKAS, Á. ${ }^{3,4}-$ SCHOFFHAUZER, J. ${ }^{5}$ - PADISÁK, J. ${ }^{1,2}$ \\ ${ }^{1}$ University of Pannonia, Department of Limnology \\ H-8200, Veszprém, Egyetem utca 10. \\ (phone: +36-88-624-747) \\ e-mail address: atrajer@gmail.com \\ ${ }^{2}$ MTA-PE Limnoecology Research Group \\ H-8200, Veszprém, Egyetem utca 10. \\ (phone: $+36-88-624-747$ ) \\ ${ }^{3}$ Hungarian Academy of Sciences, Centre for Ecological Research, \\ Institute of Ecology and Botany \\ H-2163, Vácrátót, Alkomány u. 2-4. \\ (phone: +36-28-360-122/133) \\ ${ }^{4}$ Corvinus University of Budapest, Faculty of Landscape Architecture and Urbanism, \\ Department of Garden and Open Space Design \\ H-1118, Budapest, Villányi út 29-43. \\ (phone: +36-1-482-6308) \\ ${ }^{5}$ Independent author \\ H-8227, Felsöörs, József Attila utca 14. \\ (phone: +36-20-988-5971) \\ *Corresponding author \\ e-mail: atrajer@gmail.com \\ (Received $26^{\text {th }}$ Mar 2015; accepted $4^{\text {th }}$ May 2016)
}

\begin{abstract}
Growth patterns of different plant species are primarily determined by edaphic factors, climate conditions and their species-specific adaptation properties. Changing sub-regional aridity trends due to the projected climate change like soil erosion and the invasion of alien plant species threaten the ligneous vegetation of karst areas. We aimed to study and model the potential effect of aridity on the growth rate of young individuals of the native Fraxinus ornus and its two important competitors, the exotic Pinus nigra and the aggressive invader Ailanthus altissima in a karstic forest-steppe of the Veszprém plateau, Hungary on different soil depths. Mean soil depth and the Thornthwaite agrometeorological index were used as covariates. Climate data were gained from the E-OBS gridded dataset for the period of 1950 to 2013 and from the MPI Echam5 climate model for the period of 2081 to 2100. We found significant correlation between the soil depth values and the measured heights and the average of monthly Thornthwaite agrometeorological indices. In conclusion, aridity and soil-depth have significant, but different effect on the growth patterns of the studied species. While the annual growth season of Pinus nigra and Fraxinus ornus are determined by the aridity of the months of January to May, and from February to June, respectively, the growth of Ailanthus altissima is mainly determined by the period of March to August. The climate prediction-based growth model predicts the decline of the growth patterns of each species for the 2081-2100 period in Hungary due to climate change.
\end{abstract}

Keywords: Fraxinus ornus, Pinus nigra, Ailanthus altissima, climate change, Thornthwaite agrometeorological index, aridity 


\begin{abstract}
Abbreviations: The used tree and stand abbreviations were based on the symbols of International Union of Forest Research Organizations (IUFRO) standardization (van Soest, 1965) except the values which were given in $\mathrm{cm}^{-}$based values adjusting to the young age of the stands and some new value was introduced: the standardized annual stem segment growth (hs), the the annual segment height (ha), the calculated total height of the same age trees (hc) and the measured total height of trees of similar age $(\mathrm{hm})$. The following abbreviations were used in the text: ha: annual stem offshoots growth, hs: standardized annual stem segment growth, hc: the calculated total stem height, hm: the measured total stem height, t: age from individual [years], Sm: mean soil dept, P: monthly sum of precipitation [mm], T: monthly mean temperature $\left[{ }^{\circ} \mathrm{C}\right]$, r: the growth-soil depth coefficient, TAI: Thornthwaite agrometeorological index $\left[\mathrm{mm}^{\circ} \mathrm{C}^{-1}\right]$.
\end{abstract}

\title{
Introduction
}

The protection of the natural karst vegetation against the alien plant species is one of the most important elements of the conservation for preserving integrity of the soil cover on carbonate bedrocks and the karst aquifer systems. Recently, the native vegetation is threatened by invasive species like the tree of heaven, Ailanthus altissima (Mill.) Swingle (Simaroubaceae). Some methods have been developed to control of the invasive A. altissima recommending the use of pathogens as weevils, insects, fungi or webworms (Ding et al., 2006). The substitutability of the tree-of-heaven during the changing climate with other plant species as e.g. Fraxinus ornus L. (Oleaceae) has not been numerically analyzed. F. ornus is a characteristic, widespread native ash species of the natural vegetation on dolomite and limestone karst of the South-Central Europe and the Mediterranean (Kostova, 2001). Due to their significant drought and fire tolerance (Chiatante et al., 2006), F. ornus is an important species and codominate the low canopy with Quercus pubescens Willd. (Fagaceae) in the Cotino-Quercetum pubescentis association (Csontos et al., 2001) which is common in the studied karstland area of Veszprém. Pinus nigra Arnold (Pinaceae) is an exotic tree on the dolomite rocks of the Transdanubian hills and the closest natural occurrence is in the Vienna Basin, Austria, representing the northernmost occurrence of the species in Europe (Leal et al., 2008). The dolomite terrains of the Transdanubian Mountains were intensively afforested with $P$. nigra in the $20^{\text {th }}$ century (Csontos et al., 1996). Occupying large areas on diverse dolomite rock grasslands, $P$. nigra plantations resulted in the local extinction of the original flora and fauna (Cseresznyés et al., 2006; Udvardy, 1998a) and is also known as a transformer species (Winkler and Tóth, 2012; Bódis, 1993). Ailanthus altissima, which is also a worldwide established transformer plant species (Udvardy, 1998b) is native to China, Taiwan and Northern Vietnam (Kowarik and Samuel, 2007; Ding et al., 2006). Although the members of the family of Simarubaceae are mostly tropical woody plants, $A$. altissima grows under several climatic conditions from humid or dry temperate to sub-tropical areas (Miller, 1990). As an invasive species, $A$. altissima occur in different habitats in the Mediterranean coniferous and broadleaved associations (Kowarik, 1983) and is a typical early-successional species in forest ecosystems (Robinson and Handel, 1993). Producing allopathic materials, A. altissima can suppress the growth of other angiosperms in their vicinity (Ding et al., 2006; Heisey, 1990). Although the fossil members of the Ailanthus genera are known from the Tertiary sediments of Hungary e.g. the A. confucii Unger form the Middle Miocene (Hably, 2001) and the A. tardensis Hably form Lower Oligocene (Corbett, 2004; Hably, 2001), the first specimens of A. altissima were planted in Europe only in the 1751 in France $(\mathrm{Hu}, 1979)$. A. altissima might have been introduced in Hungary in the late $18^{\text {th }}$ or the early $19^{\text {th }}$ century. According to Sárospataki (2014), the first individuals were 
planted in 1807 in Western Hungary, Keszthely then in 1814 in the archduke park of Sárvár. A. altissima has became the most important invasive species in the semi-natural forests, urban areas and dry deciduous woodlands in Hungary (Mihály and Botta-Dukát, 2004; Török et al., 2003; Udvardy, 1998b) as in many other areas of the world (Constán-Nava, 2010). A. altissima is a successful ligneous invader species on rock grasslands e.g. on the Szársomlyó Hill in the Duna-Dráva National Park in Southwestern Hungary (Erdös et al., 2005) and in the Aggtelek National Park in Northeastern Hungary (Váczi, 2001). It appears that Pinus nigra and Ailanthus altissima are the most important competitors of Fraxinus ornus in the natural rock grasslands and dry deciduous woodland habitats of Hungary. The rapid, athropogenic climate change has the potential to change the fitness of the native plant populations, and can trigger the area expansion of certain species (Huntley, 1991) dramatically altering their compositions (Jump and Peñuelas, 2005), and the degradation of the fragmented flora and fauna results in poor plant associations dominated by alien species (Gibbons et al., 2000). It is widely agreed that climate change will result expansion of many invasive species (Hellmann et al., 2008; Gritti et al., 2006; Beerling et al., 1995) as a consequence of elongation of the vegetation period, increasing winter temperatures and the increasing aridity. The process will restructure the natural vegetation with replacing natural elements by more warm-resistant, partly Mediterranean species.

Regional climate models predict an increasing aridity of the Carpathian Basin by the end of the $21^{\text {st }}$ century particularly in the vegetation period (Pieczka et al., 2011; Bartholy and Gelybó, 2007; Bartholy et al., 2009). The studied Veszprém karstland has a continental climate with warm, dry summers and mild winters. The zonal vegetation is the transition of the forest and forest steppe zones. The average annual precipitation was $650 \mathrm{~mm}$, the annual mean temperature was $9.4^{\circ} \mathrm{C}$ in the period of $1902-1950$ (Ádám et al., 1987). During 1980-2009 the annual mean temperature increased by 1.3 to $1.4^{\circ} \mathrm{C}$ in the area. In 1960-2009 the annual precipitation decreased by -5- to -15\% (Bartholy et al., 2007). In the last three decades the number of days of mean temperature higher than $25^{\circ} \mathrm{C}$ increased by 6-8 days/year (Bartholy et al., 2007). Summer precipitation is very likely to decrease for the period of 2071-2100 by -25 to $-30 \%$ according to IPCC SRES emission scenario A2 or -10 to $-15 \%$ according to scenario B2 (Strenger et al., 2004). On the other hand, winter precipitation is likely to increase by $35 \%$ (A2) or $20 \%$ (B2) (Bartholy and Gelybó, 2007).

Model results showed that the rising decay frequency of Pinus nigra individuals in the last decades was a parallel change to the decreasing growth rate of pines due to the increasing aridity trend in the Veszprém karst plateau (Trájer et al. 2015). As drought inhibits growth (Chiatante et al., 2006; Kramer and Turner 1980), in this paper, we investigate the effect of the sub-regional drought trends and the foreseen change of precipitation and temperature on the stem growth of young individuals of Fraxinus ornus and its two most important competitors: Pinus nigra and Ailanthus altissima. Our specific aims were: (1) to describe the temporal patterns of temperature and precipitation on the annual vertical growth of young individuals of the three species and (2) to model the past and predict their future vertical growth. We hypothesized that aridity in the growing period may have a great influence on the annual segment growth in the future. Since the more noticeable phase of the anthropogenic climate change started in the 1950's (King and Harangozó, 1998), we intended to model the whole period of the last six decades as well as the predicted future effect of climate change of the last two decades of the $21^{\text {st }}$ century. 


\section{Materials and methods}

\section{Study site and and soil thickness measurements}

The study was performed in the central part of the Transdanubian Highland in Hungary (Fig. 1A). The bulk of the area built up mainly of Triassic carbonates which were formed on a tropical shallow carbonate platform (Balog et al., 1997). The Triassic rocks of the Transdanubian Range belong to the Alpine Triassic type (Haas, 1992) which means that the analogies of the bedrock and the calcareous soils formed on the carbonates can be found in the entire Mediterranean Basin and the members of the Alpine orogeny as in the Alps (Goldhammer et al., 1990), in the Betic Cordillera in Spain (Martin et al., 1987). Genetically the karstic area of Veszprém belongs to the Transdanubian type which can be characterized by the significant affection of repeated tectonic movements and the faulting of the limestone and dolomite rocks into blocks (Bárány-Kevei, 2005). Due to the tectonic history, carbonate- and dolomite rubble-rich skeletal soils are characteristic to the area (Fodor et al., 2005; Márton and Fodor, 2003). The bedrock of the shallow soils is hard, cemented dolomite and limestone breccias (Fig.1B). The thickness of the shallow, dolomite bedrock soil of the plant individuals were estimated by the averaging of four manual, perpendicular soil sounding measurements with an iron sounder from $30 \mathrm{~cm}$ of the basis of the stems in each case. The thickness of the soil was defined by the depths where the probe reached the firm bedrock carbonate rock. The soil thickness data were averaged in each case. Each of the studied tree individuals grows on well-lit, open area.
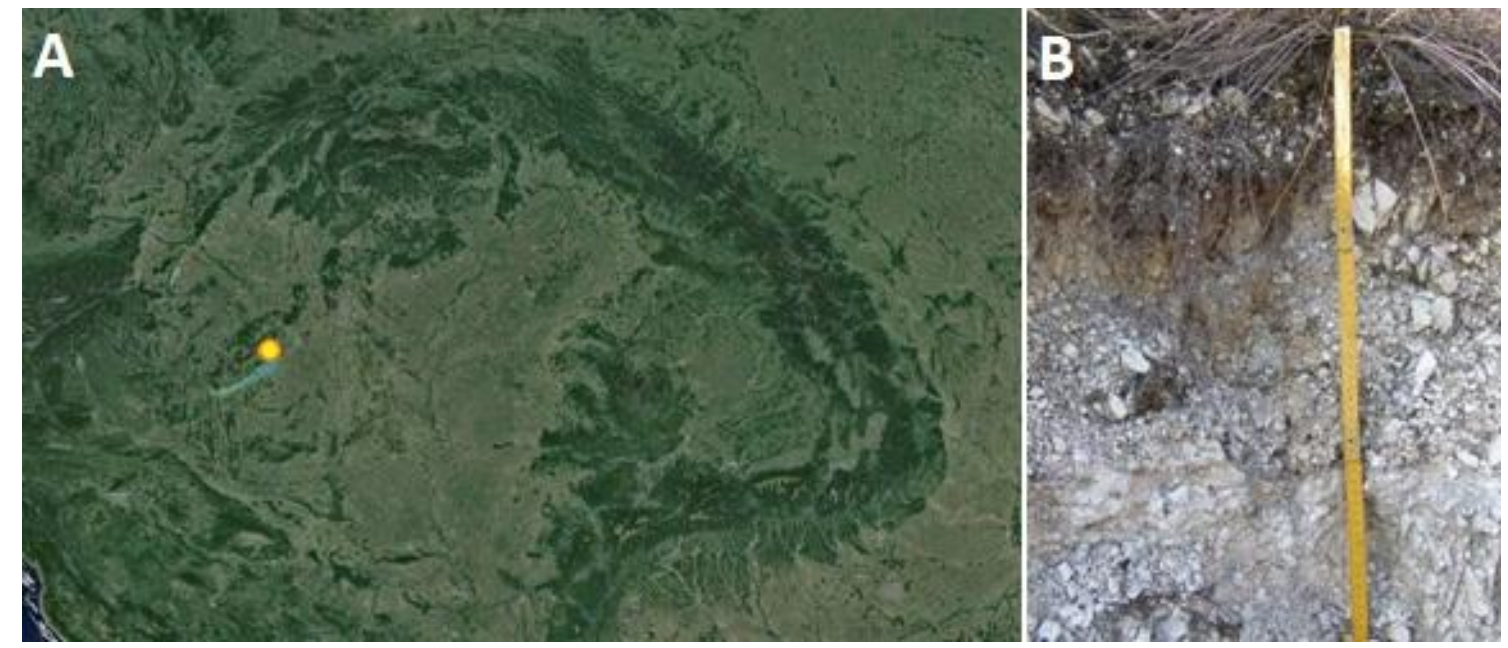

Figure 1. The studied karst region of the Carpathian Basin (yellow spot marks the place of Veszprém in the 'A' panel) and a typical section of a dolomite-based skeletal soil ('B' panel). The satellite picture was gained from the Google Earth ${ }^{T M}$ landscape visualization (Sheppard and Cizek, 2009).

\section{Measurement of the annual vertical growth of the species}

The study was based on the measurement of 491 plant individuals. A total of 205 individuals of Pinus nigra, 140 of Fraxinus ornus and 146 of Ailanthus altissima were involved in the study. We measured the stem height and the corresponding soil thickness values of 81 individuals of Pinus nigra, the 40 of Fraxinus ornus and 63 of Ailanthus altissima and the annual stem segment heights of 124 individuals of Pinus nigra, 100 of Fraxinus ornus and 83 of Ailanthus altissima. The stem heights of the 
individuals were measured from the soil level to the top of the stem. The reliably measurable number of the years varies by species, according to our observations this number is more than 11 years in Pinus nigra, about 9 years for Ailanthus altissima and 7 for Fraxinus ornus. We determined the 'segment' as the annual vertical and radial internodes between the branching levels of two adjacent years in case of Pinus nigra and the vertical dimension of a segment was measured between the two adjacent levels of the last 11 years (2004-2013). In cases of Fraxinus ornus and Ailanthus altissima the conception of the annual segments were based on the annual internodes of the plants. Seven years (2007 to 2014) were determined in case of Fraxinus ornus and nine (2005 to 2013) in case of Ailanthus altissima. The measurements in case of A. altissima were partly based on root sprout clones. We measured the individuals on well-illuminated, open areas (Fig. $2 A$ and $2 B$ ).
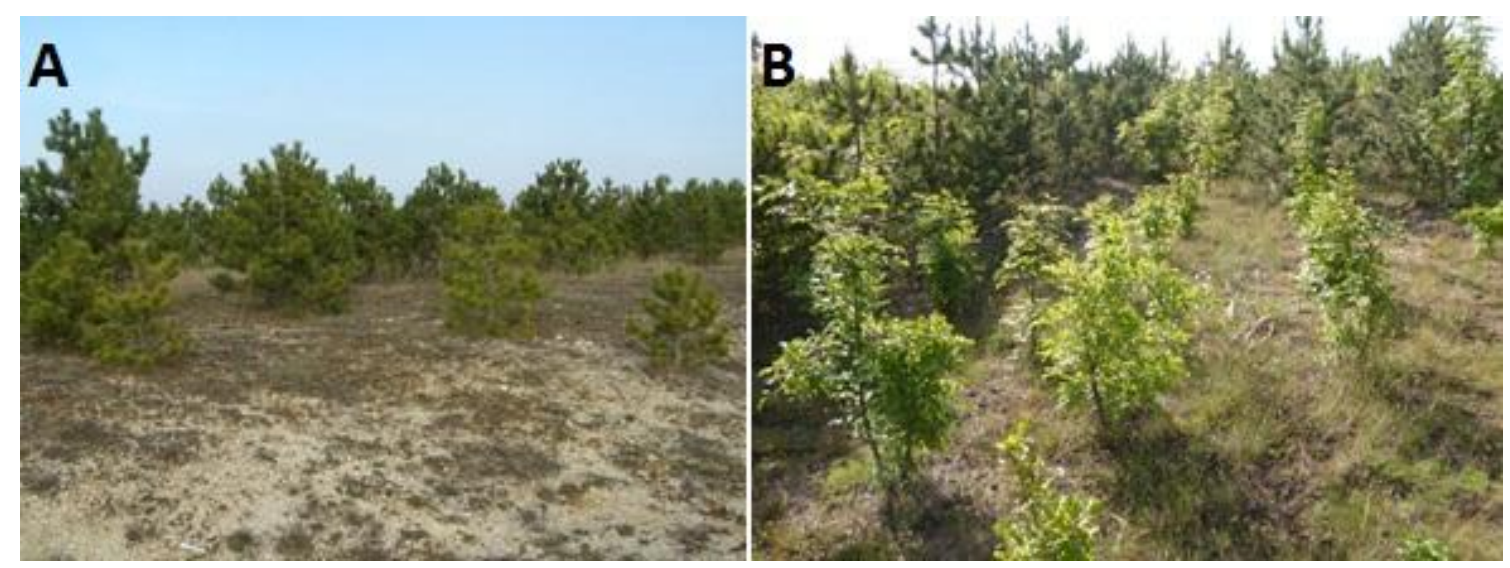

Figure 2. Characteristic landscape of the Pinus nigra (a) and Pinus nigra-Fraxinus ornus mixed plantations $(b)$ in the studied sites.

We standardized the annual segment growth values of the plants to eliminate the individual differences e.g. due to the different soil thickness, the age of the trees as the segment lengths were linearly regressed in case of each specimen and then the yearly residuals were averaged. The standardized annual stem segment growth $\left(h_{s}\right)$ was defined as the difference from the growth trend of the annual stem segments of the specimens (Fig.3A and 3B).

A

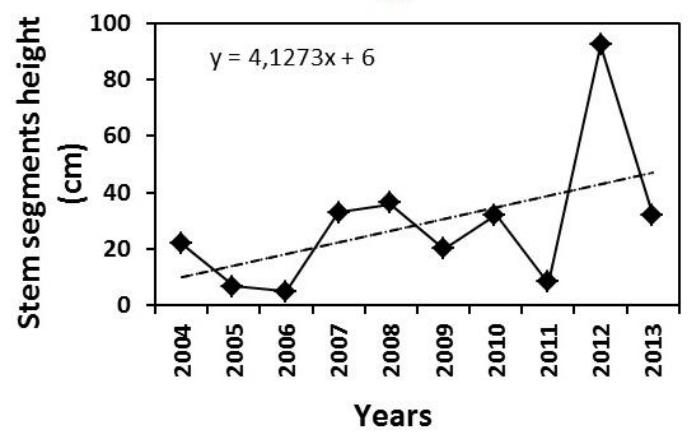

$\mathrm{B}$

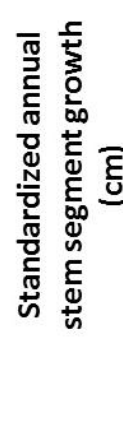

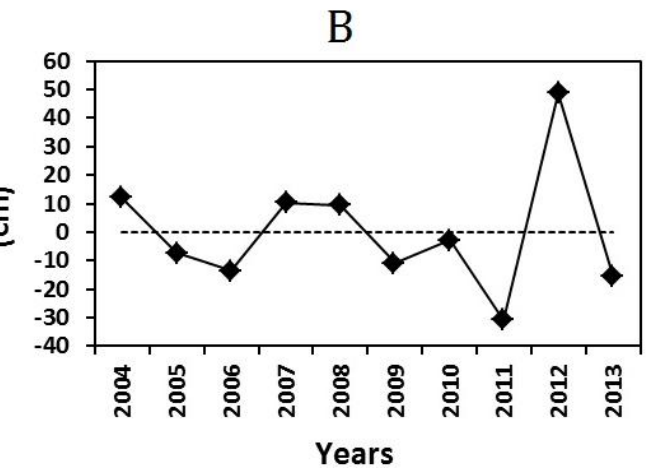

Figure 3. Example for the calculation of the used standardized annual stem segment growth $\left(h_{s}\right)$ : the annual stem segment height of a Pinus nigra individual with the equation of the growing trend (3A) and the differences from the trend (3B). 


\section{Climate data and data processing}

The monthly mean daily surface air temperature and the monthly sum of daily precipitation data of the observed period were acquired from the E-OBS gridded dataset (source: E-OBS database 2014) for $0.25^{\circ}$ grid resolution. The latitudinal expansion was $47.00^{\circ}-47.50^{\circ} \mathrm{N}$, and the longitudinal was $17.755^{\circ}-18.25^{\circ} \mathrm{E}$. The MPI Echam5 climate model was used (Jungclaus et al., 2006) which was based on the SRES A1B scenario of the period January 2081 to December 2100 (Gaffin et al., 2004). The latitudinal expansion was $46.632^{\circ}-48.496^{\circ} \mathrm{N}$, and the longitudinal was $17.813^{\circ}-19.688^{\circ} \mathrm{E}$. The slight difference of the grids was not arbitrary, originated from the differences between the databases of the observed and modelled climate. We aimed to find the most resemble grids which overlap the studied area. According to regional climate models the sum of the annual precipitation is not expected to change significantly for 2081-2100 in the region, but the modelled values of the seasonal precipitation sums show the significant redistribution of the annual precipitation patterns (Fig.4A and $4 B$ ).
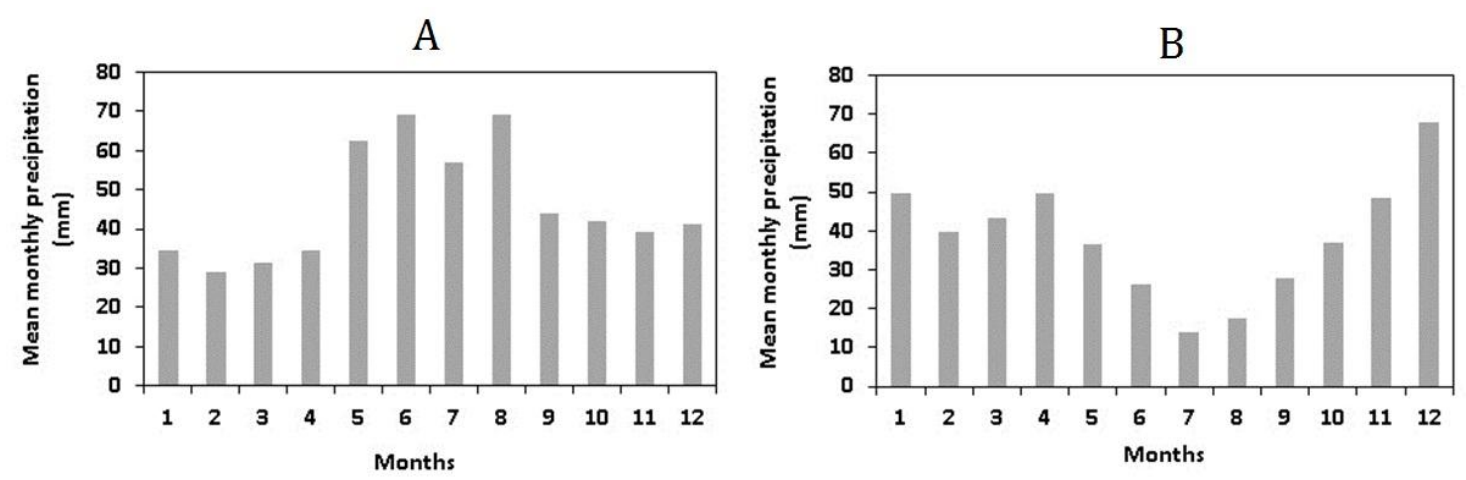

Figure 4. The mean annual distribution of the precipitation for the period of 2004-2013 (A) and the projected mean annual distribution of the precipitation for the modelled period of 2081 2100 according to the used MPI Echam5 climate model (B).

The Thornthwaite agrometeorological index (TAI) was employed as aridity index (Kemp, 1990). We averaged the monthly values during the correlations and the modeling steps.

$$
T A I=1.65 \cdot\left(\frac{P}{T+12.2}\right)^{\frac{10}{9}}
$$

\section{Correlation between the aridity index and standardized annual stem segment growth, modelling}

We studied the association between of the mean of the TAI of the months for continuous periods within the vegetation season of the year and the standardized annual stem segment growth. Continuous periods of the aridity indices of $9^{\text {th }}, 10^{\text {th }}, 11^{\text {th }}$ and $12^{\text {th }}$ months of the previous year also were involved to the study. The correlation with the best fitted significance value and $\mathrm{R}^{2}$ of the options was chosen. We used this simple method to avoid the collinearity due to the few numbers $(7,9$ and 11) of the testable years and the relatively large number of the variables (12-14). Equation of the best fit 
linear regression correlation was used as the model of the aridity-based annual growth of the species. The years of 2004 to 2013 were used as the reference periods.

We used the associations between soil thickness and the total stem heights of the same year's old individuals $(h)$ as the main factor which determines the absolute stem height. Due to the permanency of the soil thickness, in case of young individuals the soil thickness has no influence on the deviation of the individual trends. The estimation of the growth model provided a so-called "ideal" total vertical stem height according to the aridity values of the studied period starting from the height of $10 \mathrm{~cm}$ in case of Fraxinus ornus and Pinus nigra. Due to its clonal growth, in case of Ailanthus altissima we used the oldest 3 annual stem segment of the plants. Displaying the above described equations to the plantation of same aged individuals we calculated the correlation between the proportion of the measured $\left(h_{m}\right)$ and the calculated $\left(h_{c}\right)$ annual vertical growth values and the identical soil depth values.

$$
r=\frac{h_{m}}{h_{c}}
$$

The total annual vertical growth was calculated in different soil depths according to the Eq.3. Ten years of growth were modelled according to the projected monthly climate values for the soil depth of 5 to $20 \mathrm{~cm}$.

$$
h=r * h_{c}
$$

Linear Correlation and Regression were performed by the online, free statistical program pack of VassarStats website (Lowry, 2012). The Fig.11 was prepared in ArcGIS 10.1 software (Longley et al., 2001). For Fig.11-13, the different growth values of the years were sorted into attribute table. Values of the spatial data were interpolated by the IDW interpolation function of the Spatial Analyst Tool of ArcGIS.

\section{Results}

Young stems of the studied species showed rather different segment growths (Fig.5). The length of the annual stem offshoots of Fraxinus ornus showed a permanent growth (number of years $=7, R^{2}=0.05, p=0.625$ ).

$$
h_{a}=-0.0894 \bullet t+23.689
$$

In Pinus nigra a continuous growing trend was found (number of years $=11, R^{2}=0.76$, $p<0.001)$.

$$
h_{a}=1.925 \bullet t+12.567
$$

The length of the stem offshoots of Ailanthus altissima showed an exponentially decreasing trend (number of years $=9, R^{2}=0.84, p<0.001$ ). 


$$
h_{a}=1.925 \cdot \mathrm{t}+12.567
$$

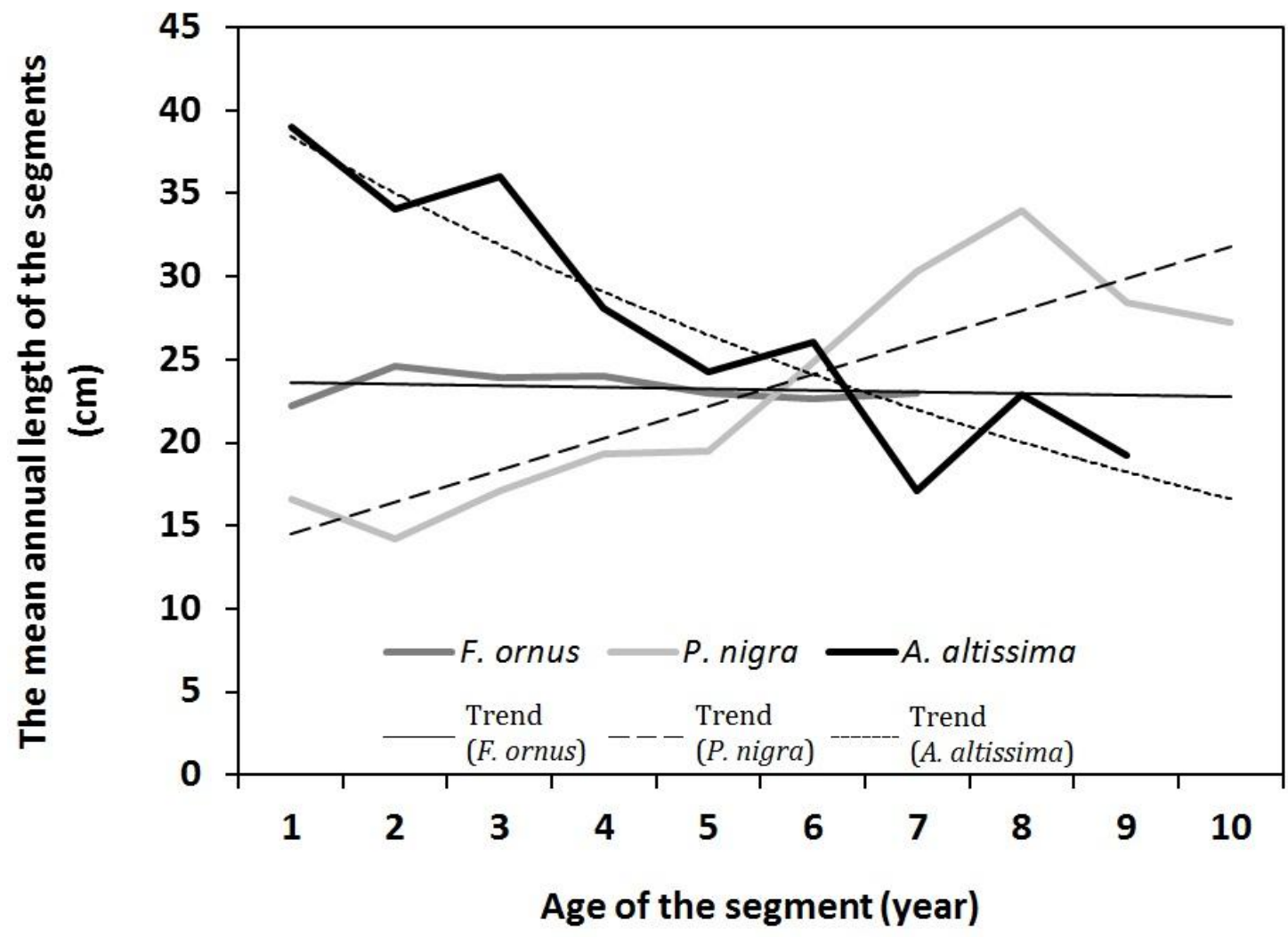

Figure 5. The trend of the length of the same years old annual segments of Fraxinus ornus, Pinus nigra and Ailanthus altissima

The averaged TAI of the following months were most significantly correlated to the standardized annual stem segment growth $\left(h_{s}\right)$ in the period of 2007 to 2013: January to June $\left(R^{2}=0.75, p=0.002\right)$, January to July $\left(R^{2}=0.73, p=0.014\right)$ and February to July $\left(R^{2}=0.70, p=0.018\right)$ in case of Fraxinus ornus; February to May $\left(R^{2}=0.70, p=0.002\right.$, Fig.7), January to May $\left(R^{2}=0.69, p=0.005\right)$ and March to May $\left(R^{2}=0.62, p=0.011\right)$ in case of Pinus nigra and March to August $\left(R^{2}=0.62, p=0.011\right)$, January to May $\left(R^{2}=0.69\right.$, $p=0.005)$ and March to May $\left(R^{2}=0.62, p=0.011\right)$ in case of Ailanthus altissima. The following equations were used in the growth models: Eq.7 (Fraxinus ornus, Fig.6A), Eq.8 (Pinus nigra, Fig.6B) and Eq.9 (Ailanthus altissima, Fig.6C).

$$
\begin{gathered}
h_{s}=1.4451 \cdot \mathrm{TAI}_{\mathrm{avg}(1,2,3,4,5,6,7)}-5.7542 \\
h_{s}=1.0579 \cdot \mathrm{TAI}_{\mathrm{avg}(2,3,4,5)}-3.7276 \\
h_{s}=1.0579 \cdot \mathrm{TAI}_{\mathrm{avg}(3,4,5,6,7,8)}-3.7276
\end{gathered}
$$


A

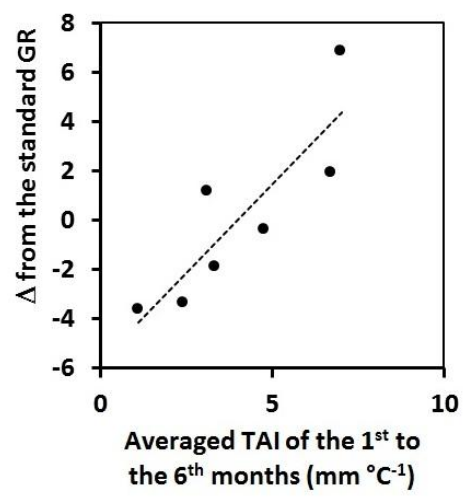

B

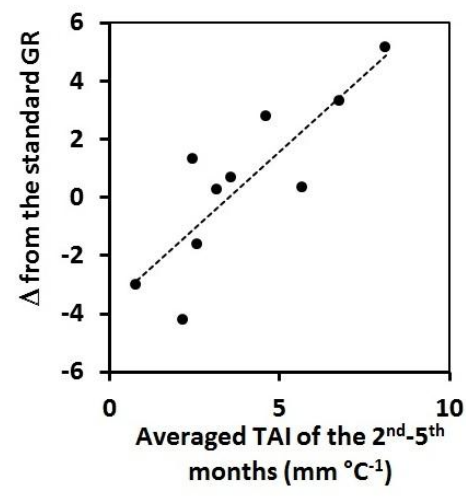

C

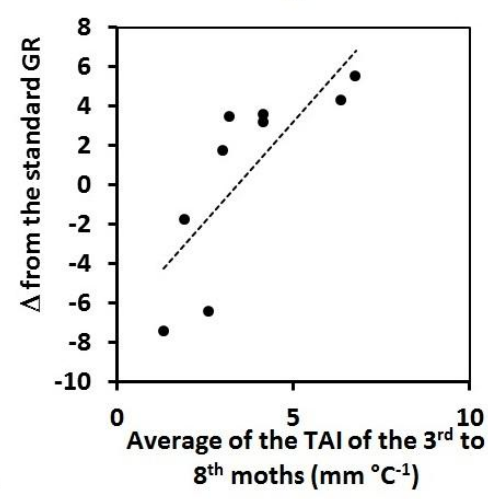

Figure 6. The association between the difference from the $h_{s}$ and the averaged TAI in case of Fraxinus ornus $\left(1^{\text {st }}\right.$ to the $6^{\text {th }}$ months; $\left.6 A\right)$, Pinus nigra $\left(2^{\text {nd }}\right.$ to the $\left.5^{\text {th }} ; 6 B\right)$, Ailanthus altissima ( $3^{\text {rd }}$ to the $8^{\text {th }}$ months; $\left.6 C\right)$.

Significant linear correlation was found between the mean soil depth and height of 7 years-old plantations of Fraxinus ornus $\left(R^{2}=0.46, p<0.001\right.$, Eq. 10) and Pinus nigra $\left(R^{2}=0.54, p<0.001\right.$, Eq.11). In case of Ailanthus altissima significant linear correlation was found between the mean soil depth and height of the oldest three annual segments $\left(R^{2}=0.21, p=0.001\right.$, Eq.12; Fig. 7).

$$
\begin{gathered}
h_{a}=7.1568 \cdot S_{m}-53.8385 \\
h=20.0345 \cdot S_{m}-24.3157 \\
h=5.2715 \cdot S_{m}-40.727
\end{gathered}
$$

We calculated the ratio between the measured and calculated height of individuals of each species of the same age (hence: ratio) according to the segment growth trend and the TAI-based growth model equations. The gained rations were regressed with the correspondent soil depth values. Significant correlation $\left(R^{2}=0.54, p<0.001\right)$ were found between the ratios of 11 years old Pinus nigra individuals according to the Eq.4 and Eq.7 using the TAI values of 2004-2013 and soil depth values. We also found significant correlation $\left(R^{2}=0.47, p<0.001\right)$ between the ratio of 7 years old Fraxinus ornus individuals according to the Eq.5 and Eq.8 using the TAI values of 2005-2013 and soil depth values. Lastly, significant correlation $\left(R^{2}=0.21, p<0.001\right)$ was found between the ratio of the 3 years old Ailanthus altissima individuals according to the Eq.6 and Eq.9 using the TAI values of 2011-2013 and soil depth values (Fig.8).

$$
\text { Ailanthus altissima: } \mathrm{r}=0.0719 \cdot S_{m}+0.5552
$$




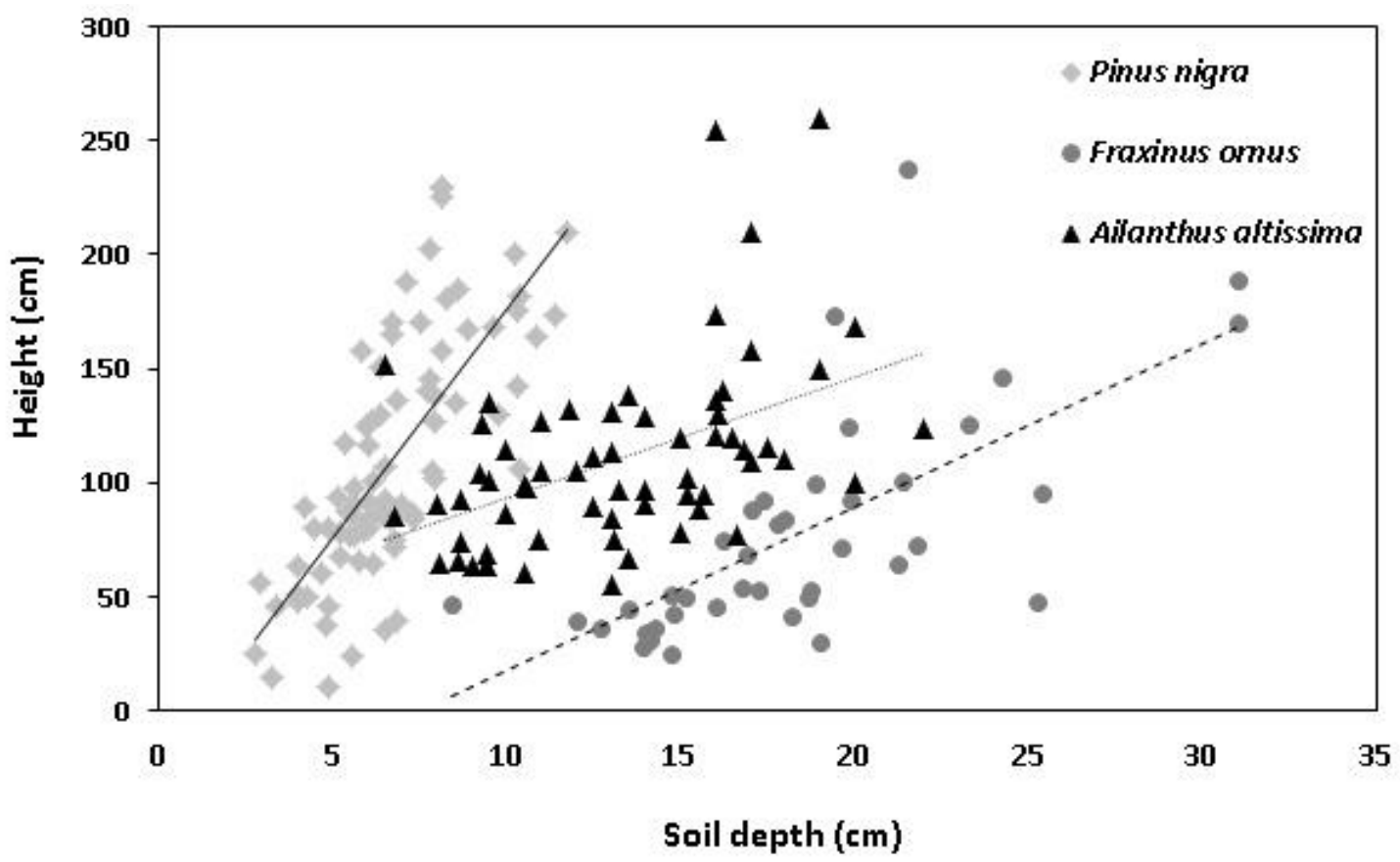

Figure 7. The correlation between the mean soil depths and the heights of 9 years old

Pinus nigra (light gray rhombus), Fraxinus ornus (dark gray circles) and the summarized length of the 3 years old Ailanthus altissima individuals (black triangles) to determine the growth-soil depth coefficient (r)

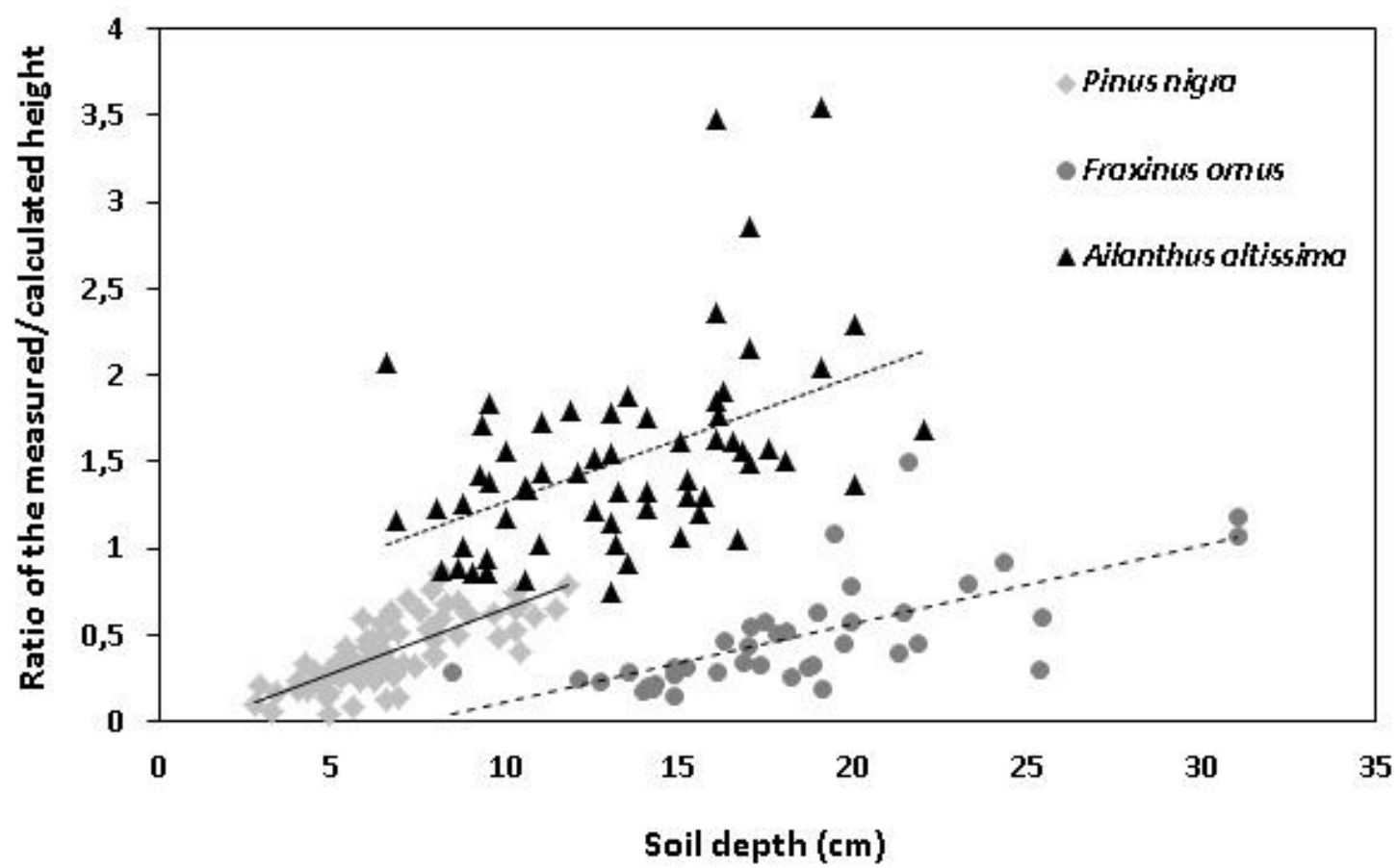

Figure 8. The correlation between the mean soil depths and the calculated per measured ratio of Pinus nigra, Fraxinus ornus and Ailanthus altissima individuals 
The model predicts the significant decrease of standardized annual stem segment growth in case of Fraxinus ornus and Ailanthus altissima during the last five decades (1950-1999): $\left[R^{2}=0.17, p=0.001\right.$; differences from the standardized stem segment growth: -0.99 (1950-1959), -1.27 (1960-1969), -1.76 (1970-1979), -1.93 (1980-1989), 2.89 (1990-1999)], $\left[R^{2}=0.07, p=0.045\right.$; differences from the standardized stem segment growth: -2.09 (1950-1959), -2.05 (1960-1969), -2.33 (1970-1979), -2.56 (1980-1989), 2.97 (1990-1999)]. In case of Pinus nigra a barely significant decrease of the standardized annual stem segment growth was found during the last six decades (19502010): $\left[R^{2}=0.07, p=0.055\right.$; differences from the standardized stem segment growth: 0.45 (1950-1959), -0.8 (1960-1969), -1.16 (1970-1979), -1.28 (1980-1989), - 1.43 (1990-1999)]. Fig.9 shows the modelled standardized annual stem segment growth of the species for the period of 1950 to 2003.

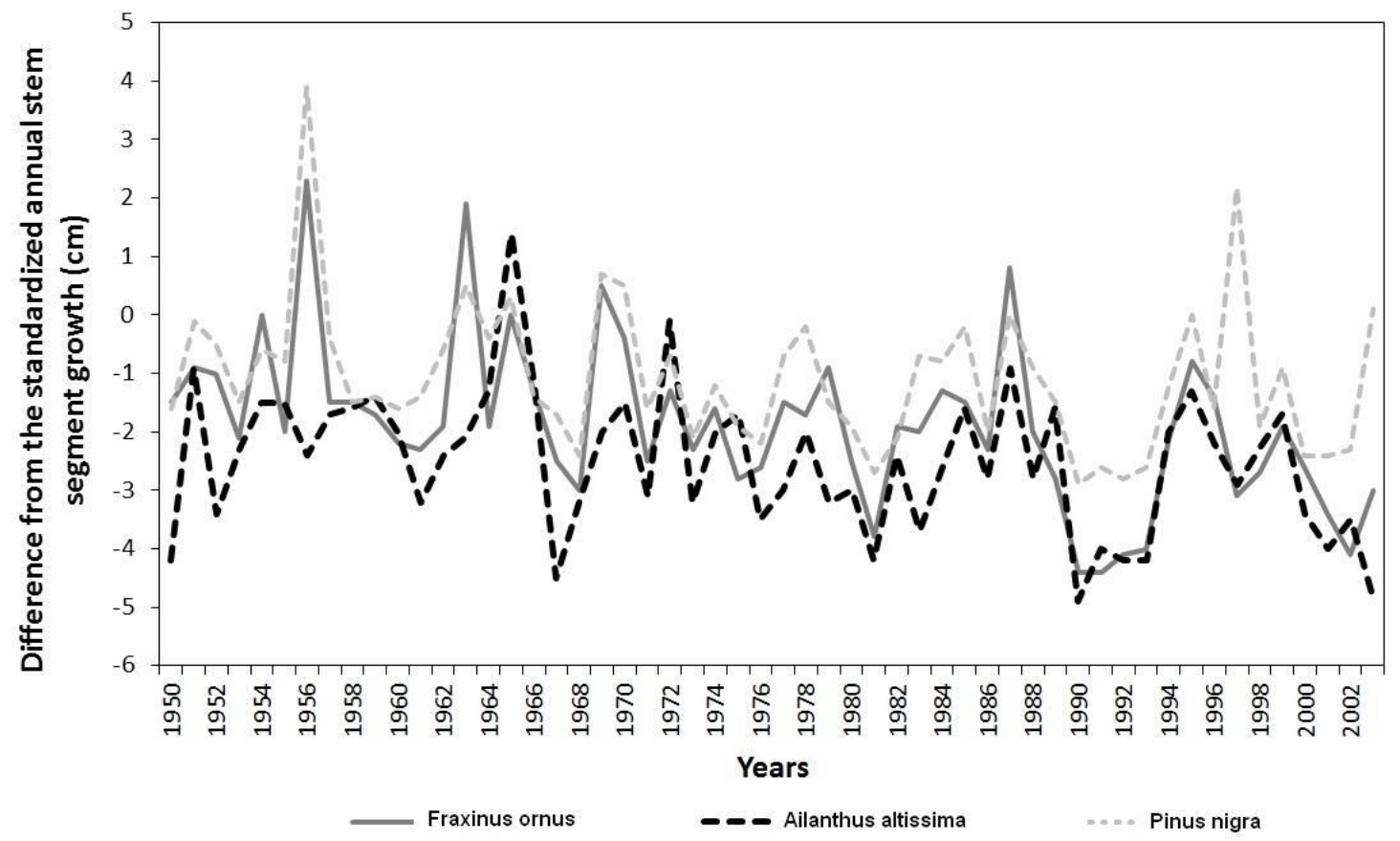

Figure 9. The modelled difference values of the standardized annual stem segment growth of Fraxinus ornus, Pinus nigra and Ailanthus altissima in cm from 1950 to 2003

The model predicts the decrease of standardized annual stem segment growth compared to the decades of the period for the future periods of 2081-2089 and 20902100: -2.54 and -2.54 (Fraxinus ornus), -4.29 and -4.64 (Ailanthus altissima), -1.55 and -1.50 (Pinus nigra; Fig. 10).

The model predicts the highest decrease of the standardized annual stem segment growth in case of Ailanthus altissima in 1950-2010, including the future period of 20812100. In case of Pinus nigra the changing climate patterns will cause a relatively low decrease of the standardized annual stem segment growth, while the change in case of Fraxinus ornus can be moderate (Fig.11). 


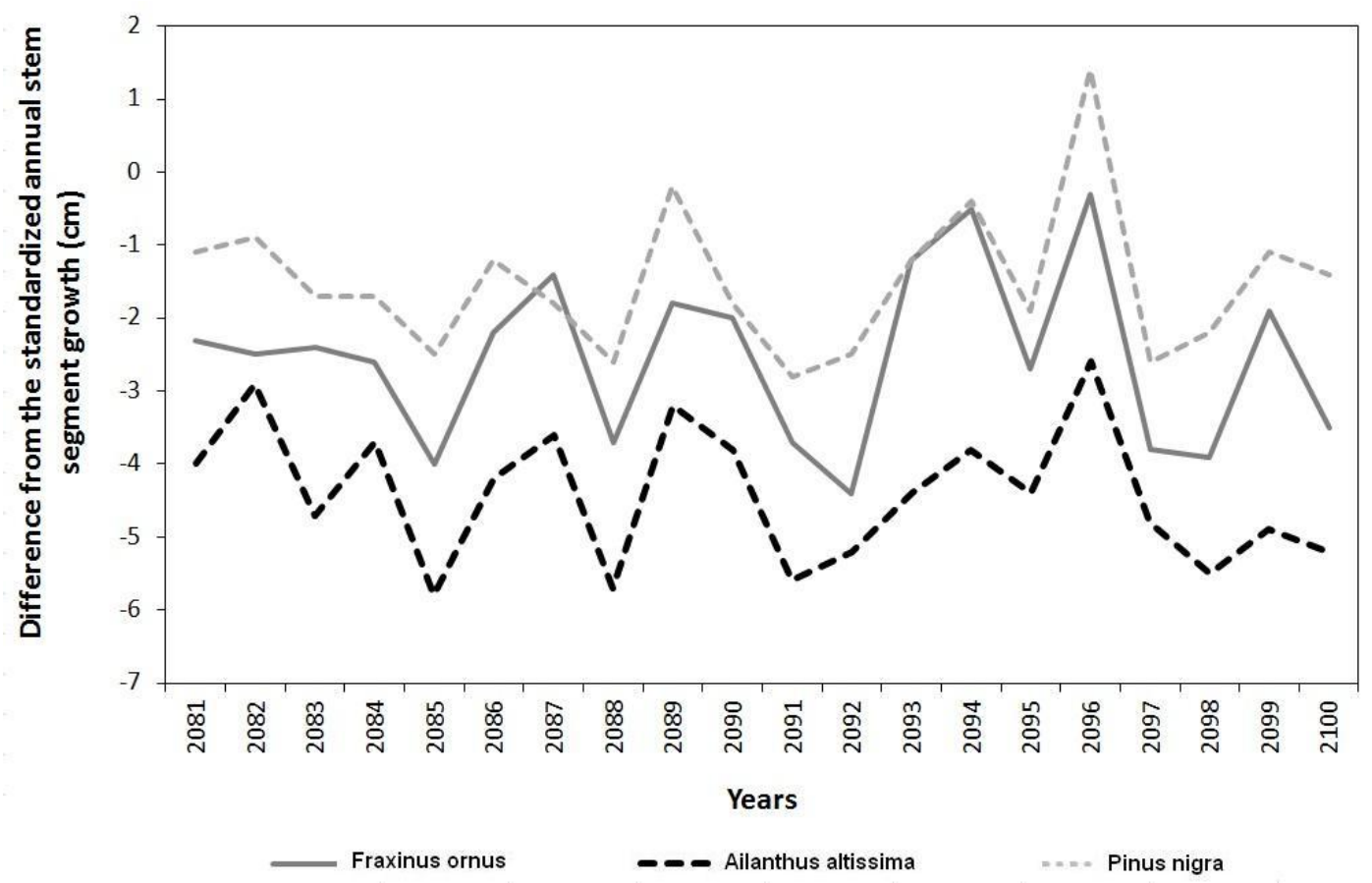

Figure 10. The modelled difference values of the standardized annual stem segment growth of Fraxinus ornus, Pinus nigra and Ailanthus altissima in cm from 2081 to 2100

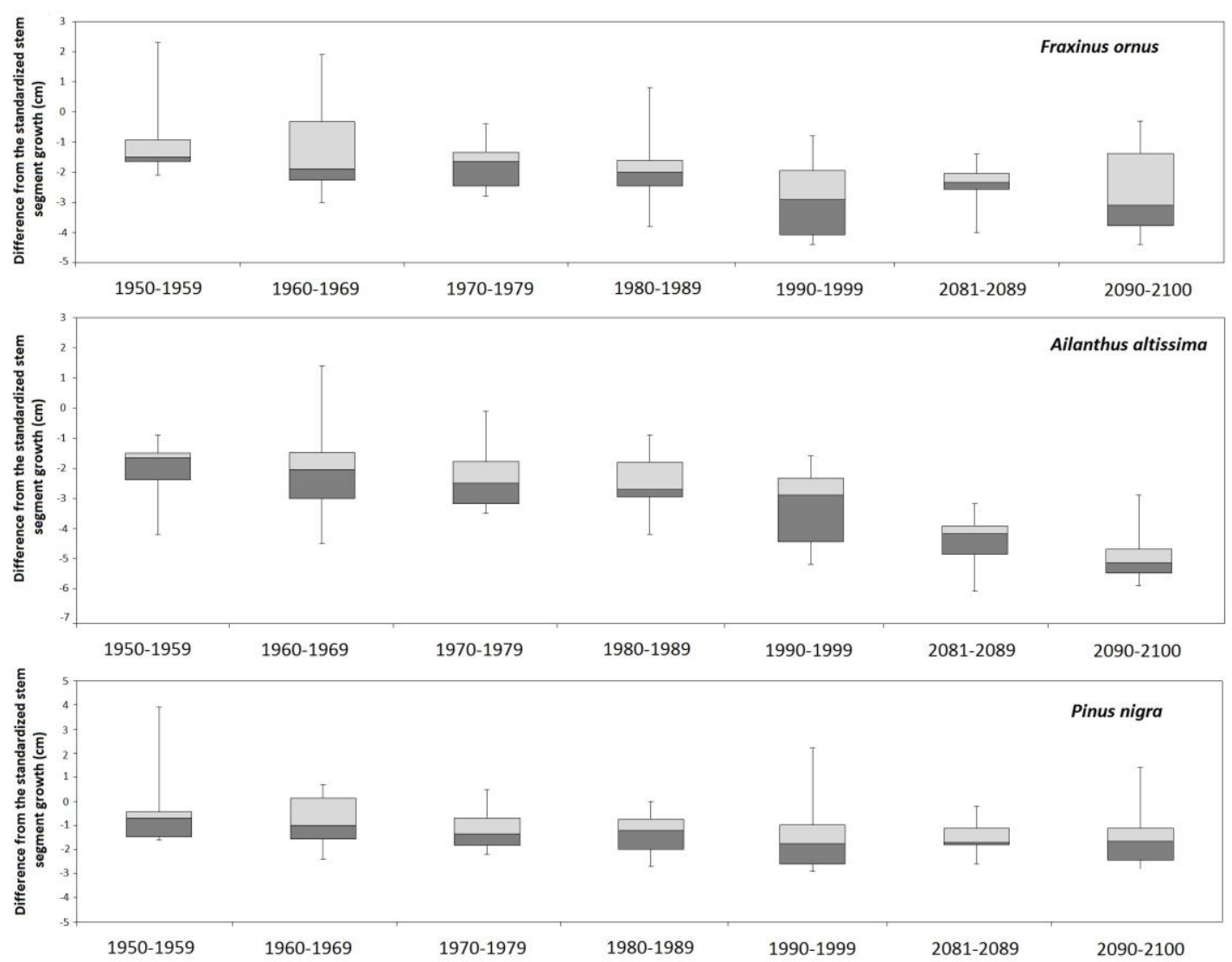

Figure 11. The box and whisker plots of the change of the modelled standardized annual stem segment growth. 
Fraxinus ornus shows the lowest absolute stem segment growth for each modelled soil depths in the period of 2091-2100 (Fig. 12).

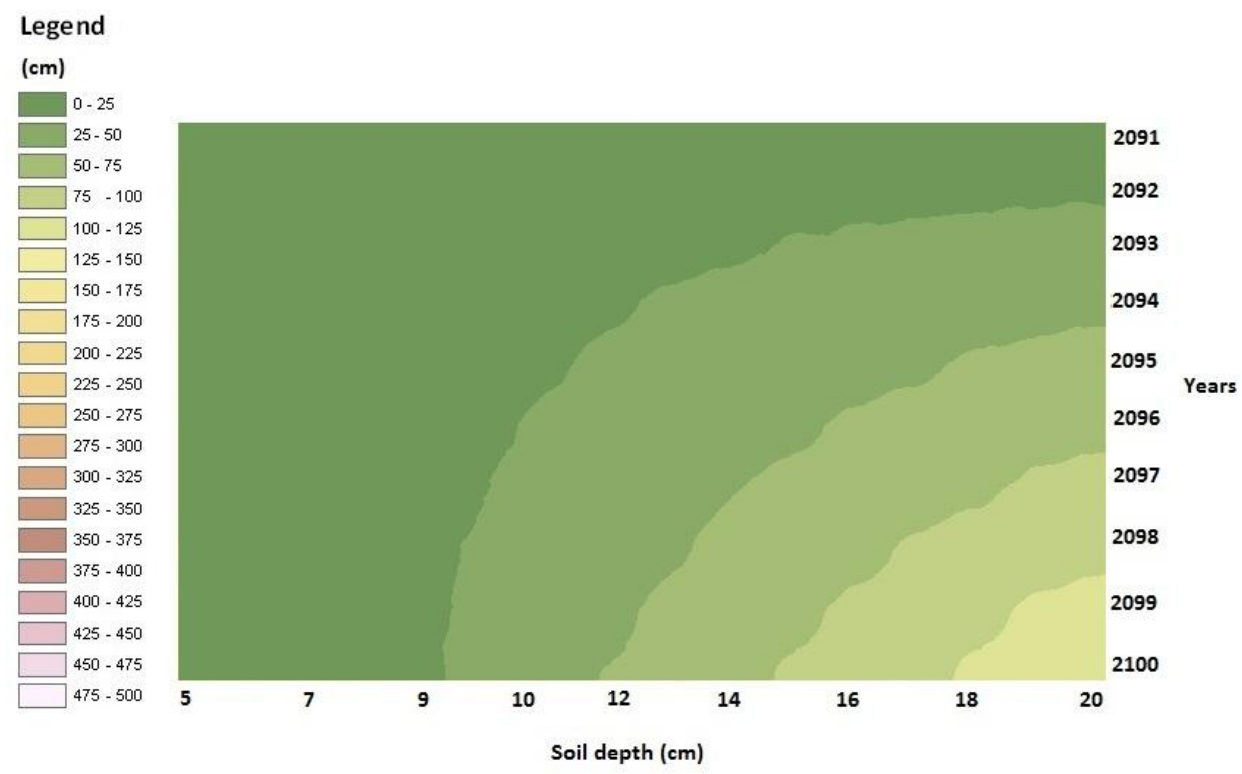

Figure 12. The modeled future (2081-2100) growth of Fraxinus ornus on soils of different deepth

The model predicts an intermediate segment growth of Pinus nigra (Fig.13).

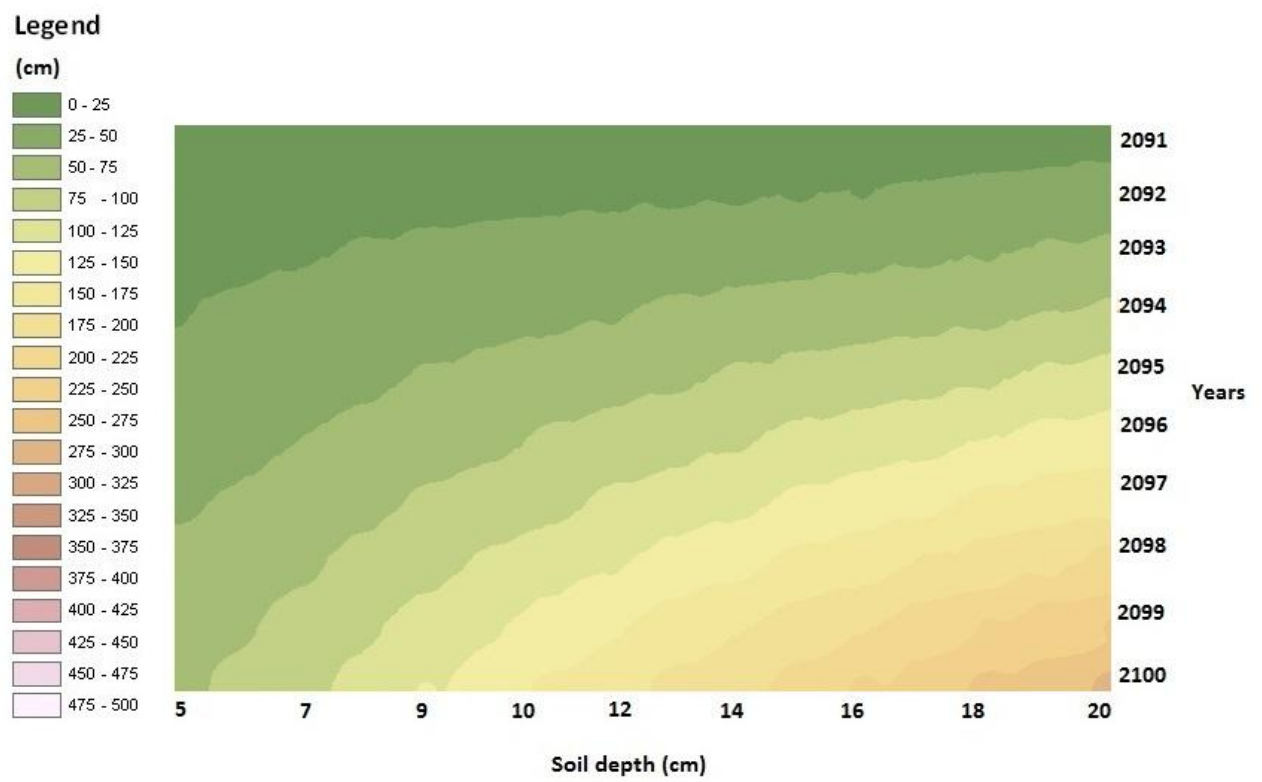

Figure 13. The modeled future (2081-2100) growth of Pinus nigra on soils of different depth

Ailanthus altissima seems to be the most rapidly growing tree species at same soil depths (Fig.14). 


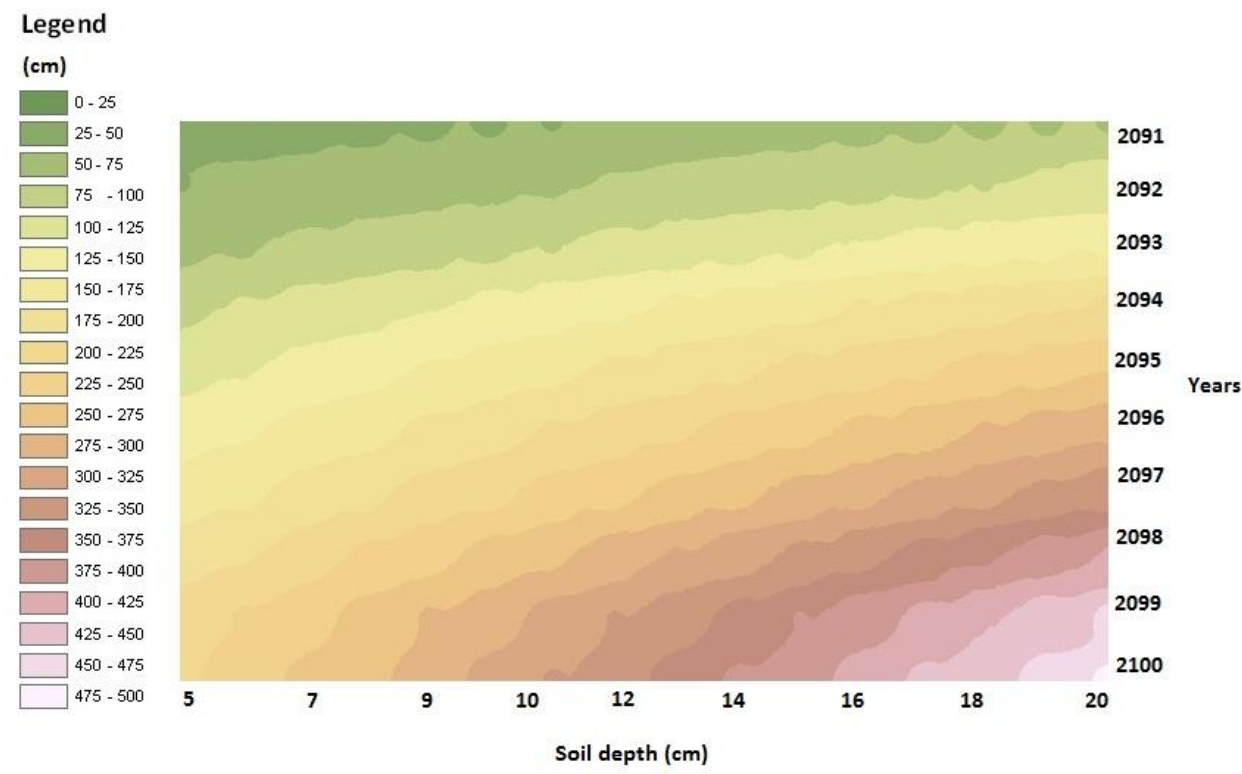

Figure 14. The modeled future (2081-2100) growth of Ailanthus altissima on soils of different deepth

\section{Discussion}

Significant differences were demonstrated between the aridity and soil-depth based growth patterns of the young specimens of Fraxinus ornus, Pinus nigra and Ailanthus altissima on the dolomite karst area of the Transdanubian Range, Hungary. While the annual growth season of the primarily South-Central European and Mediterranean Pinus nigra and Fraxinus ornus are determined by the aridity of the months of January to May or from February to June, the growth of Ailanthus altissima is mainly determined by the period of March to August. The obtained results showed similar seasonal association between the annual stem segment growth of Pinus nigra and the precipitation patterns to the ring-based study of Martín-Benito et al. (2008). MartínBenito et al. (2000) described that the early offshoots of Pinus nigra is mostly influenced by climatic conditions prior to the growing season. Wimmer et al. (2000) found a very similar association between the false rings and the precipitation of May.

It is important to note, that our model is valid only for the 1 to 10 old plants since e.g. in case of Ailanthus altissima after 10-15 years the initially branching growth pattern turns into dichasial or monochasial (Kowarik and Säumel, 2007). The model results showed that the increasing summer-spring aridity will enhance more the difference between the growth capability of Fraxinus ornus and Ailanthus altissima than in case of Fraxinus ornus and Pinus nigra therefore; Pinus nigra may overgrow the individuals of Fraxinus ornus. Although we tried to study different, non-clonal specimens of Ailanthus altissima it is possible that this aim was not totally fulfilled and hence complicates modeling and the comparison since the root sprouting plays an important role in the establishment of Ailanthus altissima in new areas (Kowarik, 1995; Rabe, 1985). It is likely that the found initial rapid segment growth of the young Ailanthus altissima clones are in accordance with the specific canopy and light gap filling strategy of the species (Knapp and Canham, 2000; Espenschied-Reilly and Runkle, 2008; Gómez-Aparicio and Canham, 2008; Call and Nilsen, 2003; 
Espenschied-Reilly and Runkle, 2008). Nevertheless, the present observations correspond to the fact that both root sprouts and seedlings can exceed a very rapid, even 1-2 m segment growth in their first year (Hunter, 1995; Miller, 1990).

The measured segment growth partly reflects the height of the species at their maturity: the average mature height of Pinus nigra ranges from 20 to $50 \mathrm{~m}$ in the natural occurrence of the species (Krugman and Jenkinson, 1974), Ailanthus altissima can reach the 18 to $21 \mathrm{~m}$ in height (Vines, 1960) and the maximum height of Fraxinus ornus is about $20 \mathrm{~m}$ on humid and rich soils (Oxford Herbaria, 2014), but it rarely exceeds 10-15 m (Kwantlen Plant Database, 2015). Although Pinus nigra reaches its mature size by approximately 80 years of age (Van Haverbeke and David, 1990), the life span of the Ailanthus altissima individuals ranges only from 30 to 70 years (Espenschied-Reilly and Runkle, 2008; Miller and James, 1990). The ramet bank of A.s altissima may explain the fast initial grow of the species in contrast to Pinus nigra and Fraxinus ornus (Kowarik, 1995). The allopathic compounds (Heisey, 1996; McFeeters, 1977) of the leaves and the barks might explain the successful colonization of the species during the decreased segment growth in later years. Kowarik (1983) described that while the distribution of Ailanthus altissima is mainly affected by site fertility in the Mediterranean, in Central Europe climate is the major factor that affects occurrence.

We found that aridity is a secondary factor of growing and soil depth is a much more important factor of absolute growth in case of all species. These results indicate that considering the climate/aridity requirements of the species, the climate of the studied area is closer to the Mediterranean climate than to the typical continental what corresponds to the sub-Mediterranean character of the Transdanubian Mountains (Németh, 2011; Bartha and Nagy, 2005). A. altissima is able to survive severe droughts on dry, rocky soils using an effective water-saving mechanism that includes decreasing the water loss by leaves and reducing the root hydraulic conductance (Trifilò et al., 2004). Vertical growth of A. altissima is also sensitive to aridity, but A. altissima has advantage in the absolute annual growth against Pinus nigra and Fraxinus ornus due to its rapid growth in the first years. A. altissima showed the greatest growth on shallow soils which is in accordance with the observations that its seedlings often occupy the pavement cracks and other dry sites (Graves et al., 1989), e.g. wall cracks and flat concrete roofs, moreover can tolerate compacted soils (Miller, 1990; Pan and Bassuk, 1985). Pinus nigra also showed great tolerance against the shallow, calcareous soil. Similar to Ailanthus altissima, Pinus nigra in their natural occurrence lives in various soil types and is able to live near the sea tolerating dry, shallow soils, sands, chalks, and limestone soils (Haverbeke, 2014). P. nigra is characterized by a relatively rapid, cca 15 to $34 \mathrm{~cm}$ annual growth which, moreover, showed an accelerating trend in the first 11 years. The maximum of the measured segment growth is very close to the growth of the $P$. nigra individuals of the Great Plain where approximately a $30 \mathrm{~cm}$ yearly segment growth was measured on "average sites" in the first 20 years after planting (Sander, 1963). The modeled $300 \mathrm{~cm}$ stem length of the 10-years old P. nigra individuals on 20 $\mathrm{cm}$ deep soils is comparable to the $5.3 \mathrm{~m}$ height of the same year's individuals which was measured in the Secrest Arboretum at Ohio State University on deep, rich soils (Aughanbaugh, 1958).

A. altissima is able to become a dominant species on disturbed calcareous vegetation (Patterson, 2008). Although Fraxinus ornus in Central and Eastern Europe also lives mainly on dry chalk and dolomite rocks soils (Oxford Herbaria, 2014) we found slightly slower segment growth on shallow soils than for Pinus nigra and Ailanthus altissima 
which can be a consequence the extensive root system of the Fraxinus ornus requiring deeper soils (Oxford Herbaria, 2014). Our findings confirm the importance of the effective treatment of re-naturalized areas at least in the first decades since the segment growth of the native Fraxinus ornus is significantly slower than that of the offshoots of Ailanthus altissima.

Emission models suggest the increase of the atmospheric carbon-dioxide concentration which may have beneficial effects on plant growth. For example, Kaushal et al. (1989) found that the height of the seedlings of Pinus nigra in their $2^{\text {nd }}$ growth year was $10 \%$ more at $800 \mu \mathrm{mol}^{\circ} \mathrm{mol}^{-1}$ carbon-dioxide atmosphere than under the the 'normal' $350 \mu \mathrm{mol} \cdot \mathrm{mol}^{-1}$. Several further studies investigated the effects of elevated $\mathrm{CO}_{2}$ level on tree growth (Kilpeläinen et al., 2003; Broadmeadow et al., 2000; Kaushal et al., 1989), but these studies in general agreed that other factors (like low soil nutrient availability, decreasing precipitation, unbalanced water supply, increasing atmospheric ozone concentration (Broadmeadow et al., 2000; Curtis, 1996; Lal, 2004; Nearing et al., 2004), can reduce or reverse the proposed positive effect of the increasing $\mathrm{CO}_{2}$ concentration on plant growth. This effect can be particularly relevant for dry deciduous woodland vegetation which a priori grows on shallow soils. Due to the inconsistent, complex influence and the lacking experimental data of the studied species, the effect of the elevating atmospheric carbon-dioxide concentration was omitted from the model presented in thes paper. Additionally, climate change may increase the risk of forest fires in the Mediterranean areas (Moriondo et al., 2006) and the fitness of Pinus nigra individuals can be considerably influenced by fungal infections during severe droughts in Hungary (Koltay et al., 2005).

Since climate models predict the Mediterranean-like rearrangement of the annual precipitation patterns in the Carpathian Basin (Bartholy et al., 2009, 2007), the native Fraxinus ornus may have a slight long-term advantage in contrast to Ailanthus altissima since Fraxinus ornus also has the ability of rapid invasion (Thebaud and Debussche, 1991) what can be supported by the continuous growth strategy of the species. In long term, replacement of Pinus nigra by Fraxinus ornus may be successful. Although conifers can successfully occupy canopy gaps from the seed bank (Daskalakou and Thanos, 1996), the seedling density strongly decreases with stand age (Augosto et al., 2001) and some of the species of the original dolomite grassland and dry deciduous woodland vegetation have a long-term persistent seed bank under Pinus nigra plantations (Csontos et al., 1996). The models predict that $F$. ornus will be a useful candidate of re-naturalizations if the necessary treatments will also be performed combined with the removal of Pinus nigra and Ailanthus altissima. Since Fraxinus ornus generally grows in mixed forests with oak and pine (Gratani and Foti, 1998) there is chance that the $F$. ornus will replace the Pinus nigra plantations because the invasion of Ailanthus is partly prohibited by the high light demand of the species in closed associations (Botta-Dukát, 2008; Kowarik and Säumel, 2007). It should be emphasized that we did not study the effect of the increasing shading on growth rates. The subsequent treatment is also important since Ailanthus altissima can survive in poorly lit environments while may be shrubby if suppressed beneath the canopy (Váczi, 2011). Our results showed that the reconstruction of the native dry deciduous woodland associations with Fraxinus ornus can be executed only with the continuous parallel removal of Ailanthus altissima due to the similar aridity tolerance and soil requirements of the species. The model predicts the similar affection of the annual growth of the species in the future due to the increasing aridity. Although Pinus nigra also threaten 
the re-naturalization of the dolomite grasslands, the removal of the pine species may be more easily executed than the eradication of Ailanthus altissima.

Acknowledgements. The study was supported by the projects TÁMOP 4.2.2. A-11/1/KONV-2012-0064, 1.1 and TÁMOP-4.2.1/B-09/1/KMR-2010-0005. We thank Gyula Schoffhauzer for the field assistance.

\section{REFERENCES}

[1] Ádám, L., Marosi, S., Szilárd, J. (1987): A Dunántúli-középhegység. - Akadémiai kiadó, Budapest, p. 500. [in Hungarian]

[2] Aughanbaugh, J. E., Muckley H. R., Diller, O. D. (1958): Performance records of woody plants in the Secrest Arboretum. - Ohio Agricultural Experiment Station, Departmental Series 41. Columbus. 90 p.

[3] Augusto, L., Dupouey, J. L., Picard, J. F, Ranger, J. (2001): Potential contribution of the seed bank in coniferous plantations to the restoration of native deciduous forest vegetation. - Acta Oecologica 22: 87-98.

[4] Balog, A., Haas, J., Read, J. F., Coruh, C. (1997): Shallow marine record of orbitally forced cyclicity in a Late Triassic carbonate platform, Hungary. - Journal of Sedimentary Research 67: 661-675

[5] Bárány-Kevei, I. (2005): Genetic types, human impact and protection of Hungarian karsts. - Acta Climatol Chorol Univ Szegediensis 38-39: 17-23.

[6] Bartholy, J., Pongracz, R., Torma, C., Pieczka, I., Kardos, P., \& Hunyady, A. (2009): Analysis of regional climate change modelling experiments for the Carpathian basin. International Journal of Global Warming 1: 238-252.

[7] Bartha, D., Király, G., Vidéki, R., Nagy A., (2005): Occurrence of Rare Tree and Shrub Species in Hungary. - Acta Silvatica Lignaria Hungarica 1: 9-23.

[8] Bartholy, J., Pongrácz, R., Gelybó, Gy. (2007): Regional climate change expected in Hungary for 2071-2100. - Applied Ecology and Environmental Research 5: 1-17.

[9] Beerling, D. J., Huntley, B., Bailey, J. P. (1995): Climate and the distribution of Fallopia japonica: use of an introduced species to test the predictive capacity of response surfaces. - Journal of Vegetation Science 6: 269-282.

[10] Bódis, J. (1993): The effect of Pinus nigra on open dolomite grass-lands. I. Textural changes (A feketefenyő hatása nyílt dolomitsziklagyepre. I. Texturális változások.). Botanikai Közlemények 80: 129-139.

[11] Botta-Dukát, Z. (2008): Invasion of alien species to Hungarian (semi-) natural habitats. Acta Botanica Hungarica 5(Supp1): 219-227.

[12] Broadmeadow, M. S., Jackson, S. B. (2000): Growth responses of Quercus petraea, Fraxinus excelsior and Pinus sylvestris to elevated carbon dioxide, ozone and water supply. - New Phytologist 146: 437-451.

[13] Call, L. J., Nilsen, E. T. (2003): Analysis of spatial patterns and spatial association between the invasive tree-of-heaven (Ailanthus altissima) and the native black locust (Robinia pseudoacacia). - The American Midland Naturalist 150: 1-14.

[14] Corbett, S. L., Manchester, S. R. (2004): Phytogeography and fossil history of Ailanthus (Simaroubaceae). - International Journal of Plant Sciences 165: 671-690.

[15] Csontos, P., Tamás, J., Kalapos, T., (2001): Correlation between age basal diameter of Fraxinus ornus L. in three ecologically contrasting habitats. - Acta Botanica Hungarica 43: 127-136.

[16] Csontos, P., Horánszky, A., Kalapos, T., Lõkös, L. (1996): Seed bank of Pinus nigra plantations in dolomite rock grassland habitats, and its implications for restoring of the 
grassland vegetation. - Hungarian Natural History Museum. In Annales Historico Naturales-Musei Nationalis Hungarici 88: 69-78.

[17] Cseresznyés, I., Csontos, P., Bózsing, E. (2006): Stand age influence on litter mass of Pinus nigra plantations on dolomite hills in Hungary. - Botany 84: 363-370.

[18] Chiatante, D., Iorio, A. D., Sciandra, S., Scippa, G. S., Mazzoleni, S. (2006): Effect of drought and fire on root development in Quercus pubescens Willd. and Fraxinus ornus L. seedlings. - Environmental And Experimental Botany 56: 190-197.

[19] Constán-Nava, S., Bonet, A., Pastor, E., Lledó, M. J. (2010): Long-term control of the invasive tree Ailanthus altissima: Insights from Mediterranean protected forests. - Forest Ecology and Management 260: 1058-1064.

[20] Curtis, P. S. (1996): A metaanalysis of leaf gas exchange and nitrogen in trees grown under elevated carbon dioxide. - Plant, Cell \& Environment 19: 127-137.

[21] Daskalakou, E. N., Thanos, C. A. (1996): Aleppo pine (Pinus halepensis) postfire regeneration: the role of canopy and soil seed banks. - International Journal of Wildland Fire 6: 59-66.

[22] Ding, J., Wu, Y., Zheng, H., Fu, W., Reardon, R., Liu, M. (2006): Assessing potential biological control of the invasive plant, tree-of-heaven, Ailanthus altissima. - Biocontrol Science and Technology 16: 547-566.

[23] E-OBS database (2014): http://www.ecad.eu/download/ensembles/ensembles.php. Last accessed in 05032015

[24] Espenschied-Reilly, A. L., Runkle, J. R. (2008): Distribution and Changes in Abundance of Ailanthus altissima (Miller) Swingle in a Southwest Ohio Woodlot. - Ohio Journal of Science 108: 16-22.

[25] Erdős, L., Márkus, A., Körmöczi, L. (2005): Consequences of an extirpation trial of Ailanthus altissima (Ailanthus altissima (Mill.) Swingle) on rock grasslands and slope steppes. - Tiscia (Szeged) 35: 3-7.

[26] Fodor, L., Csillag, G., Németh, K., Budai, T., Cserny,T., Martin, U., Dewey , J. (2005): Tectonic development, morphotectonics and volcanism of the Transdanubian Range: a field guide. - Occasional Papers of the Geological Institute of Hungary 204: 59-86.

[27] Gaffin, S. R., Rosenzweig, C., Xing, X., Yetman, G. (2004): Downscaling and geo-spatial gridding of socio-economic projections from the IPCC Special Report on Emissions Scenarios (SRES). - Global Environmental Change 14: 105-123.

[28] Gómez-Aparicio, L., Canham, C. D. (2008): Neighbourhood analyses of the allelopathic effects of the invasive tree Ailanthus altissima in temperate forests. - Journal of Ecology 96: 447-458.

[29] Goldhammer, R. K., Dunn, P. A., Hardie, L. A. (1990): Depositional cycles, composite sea-level changes, cycle stacking patterns, and the hierarchy of stratigraphic forcing: examples from Alpine Triassic platform carbonates. - Geological Society of America Bulletin 102: 535-562.

[30] Gratani, L., Foti, I. (1998): Estimating forest structure and shade tolerance of the species in a mixed deciduous broad-leaved forest in Abruzzo, Italy. - In Annales Botanici Fennici 35: $75-83$

[31] Graves, W. R., Dana, M. N., Joly, R. J. (1989): Influence of Root-zone Temperature on Growth of Ailanthus altissima (Mill.) Swingle1. - Growth Regul 5: 163-167.

[32] Gritti, E. S., Smith, B., Sykes, M. T. (2006): Vulnerability of Mediterranean Basin ecosystems to climate change and invasion by exotic plant species. - Journal of Biogeography 33: 145-157.

[33] Gibbons, J. W., Scott, D. E., Ryan, T. J., Buhlmann, K. A., Tuberville, T. D., Metts, B. S., Winne, C. T. (2000): The Global Decline of Reptiles, Déjà Vu Amphibians Reptile species are declining on a global scale. Six significant threats to reptile populations are habitat loss and degradation, introduced invasive species, environmental pollution, disease, unsustainable use, and global climate change. - BioScience 50: 653-666. 
[34] Haas, J. (1982): Facies analysis of the cyclic Dachstein Limestone Formation (Upper Triassic) in the Bakony Mountains, Hungary. - Facies 6: 75-83.

[35] Hellmann, J. J., Byers, J. E., Bierwagen, B. G., Dukes, J. S. (2008): Five potential consequences of climate change for invasive species. - Conservation Biology 22: 534543.

[36] Hably, L. (2001): Fruits and leaves of Ailanthus Desf. from the Tertiary of Hungary. Acta Palaeobotanica 41: 207-219.

[37] Heisey, R. M. (1996): Identification of an allelopathic compound from Ailanthus altissima (Simaroubaceae) and characterization of its herbicidal activity. - American Journal of Botany 83: 192-200.

[38] Heisey, R. M. (1990): Allelopathic and herbicidal effects of extracts from tree of heaven (Ailanthus altissima). - American Journal of Botany 77: 662-670.

[39] Haverbeke, D. F. V. (2014): European Pinus nigra.

[40] http://www.na.fs.fed.us/pubs/silvics_manual/Volume_1/pinus/nigra.htm. Last accessed in 23052014

[41] Huntley, B. (1991): How plants respond to climate change: migration rates, individualism and the consequences for plant communities. - Annals of Botany 67(Supp1): 15-22.

[42] Hunter, J. C. (1995): Ailanthus altissima (Miller) Swingle: its biology and recent history. - California Exotic Pest Plant Council News 3: 4-5.

[43] Jacob, D., Podzun, R. (1997): Sensitivity studies with the regional climate model REMO. - Meteorology and Atmospheric Physics 63: 119-129.

[44] Jump, A. S., Penuelas, J. (2005): Running to stand still: adaptation and the response of plants to rapid climate change. - Ecology Letters 8: 1010-1020.

[45] Jungclaus, J. H., Keenlyside, N., Botzet, M., Haak, H., Luo, J. J., Latif, M., Roeckner E. (2006): Ocean circulation and tropical variability in the coupled model ECHAM5/MPIOM. - Journal of Climate 19: 3952-3972.

[46] Kaushal, P., Guehl, J. M., Aussenac, G. (1989): Differential growth response to atmospheric carbon dioxide enrichment in seedlings of Cedrus atlantica and Pinus nigra ssp. Laricio var. Corsicana. - Canadian Journal of Forest Research 19: 1351-1358.

[47] Kemp, D. (2002): Global environmental issues: a climatological approach. - Routledge, London, $217 \mathrm{p}$.

[48] Kilpeläinen, A., Peltola, H., Ryyppö, A., Sauvala, K., Laitinen, K., Kellomäki, S., (2003): Wood properties of Scots pines (Pinus sylvestris) grown at elevated temperature and carbon dioxide concentration. - Tree Physiology 23: 889-897.

[49] King, J. C., Harangozó, S. A. (1998): Climate change in the western Antarctic Peninsula since 1945: observations and possible causes. - Annals of Glaciology 27: 571-575.

[50] Koltay, A., Kövics, G. J., Dávid, I. (2005): Health condition of Hungarian forestsappearance of new disease. - In: 10. Tiszántúli Növényvédelmi Fórum, Debrecen, Hungary 130-140.

[51] Knapp, L. B., Canham, C. D. (2000): Invasion of an old-growth forest in New York by Ailanthus altissima: sapling growth and recruitment in canopy gaps. - Journal of the Torrey Botanical Society 127: 307-315.

[52] Kostova, I, (2001). Fraxinus ornus. L. Fitoterapia 72: 471-480.

[53] Kowarik, I., Säumel, I. (2007): Biological flora of Central Europe: Ailanthus altissima (Mill.) Swingle. - Perspectives in Plant Ecology, Evolution and Systematics 8: 207-237.

[54] Kowarik, I. (1995): Clonal growth in Ailanthus altissima on a natural site in West Virginia. - Journal of Vegetation Science 6: 853-856.

[55] Kowarik, I. (1983): Colonization by Ailanthus altissima (Ailanthus altissima) in the French mediterranean region (Bas-Languedoc), and its phytosociological characteristics. - Phytocoenologia 11: 389-405. 
[56] Kramer, P. J., Turner, N. C. (1980): Drought, stress, and the origin of adaptations. - In: Turner N.C. Kramer P.J. (Eds.)- Adaptation of plants to water and high temperature stress, 7 Functional Plant Biology 13: 175-190.

[57] Krugman, S. L., Jenkinson, J. L. (1974): Pinaceae pine family. In: Schopmeyer, C.S., Seeds of woody plants in the United States. - Agriculture Handbook, Washington, Department of Agriculture Forest Service 598-637.

[58] Kwantlen (Politechnic University) Plant Database. https://plantdatabase.kwantlen.ca/plant/plantDetail/925. Last accessed in 19032015

[59] Lal, R. (2004): Soil carbon sequestration impacts on global climate change and food security. - Science 304: 1623-1627.

[60] Leal, S., Eamus, D., Grabner, M., Wimmer, R., Cherubini, P. (2008): Tree rings of Pinus nigra from the Vienna basin region (Austria) show evidence of change in climatic sensitivity in the late 20th century. - Canadian Journal of Forest Research 38: 744-759.

[61] Loáiciga, H. A., Maidment, D. R., Valdes, J. B. (2000): Climate-change impacts in a regional karst aquifer, Texas, USA. - Journal of Hydrology 227: 173-194.

[62] Longley, P. A., Goodchild, M. F., Maguire, D. J., Rhind, D. W. (2001). Geographic information system and Science, 2nd Edition. - England: John Wiley \& Sons, Ltd,. Chichester $537 \mathrm{p}$.

[63] Lowry R., (2012): VassarStats: Website for statistical computation. Vassar College. http://vassarstats.net/. Last accessed in 19032015

[64] Martin, J. M., Torres-Ruiz J., Fontboté, L. (1987): Facies control of strata-bound ore deposits in carbonate rocks: the F-(Pb-Zn) deposits in the Alpine Triassic of the Alpujárrides, southern Spain. - Mineralium Deposita 22: 216-226.

[65] Martín-Benito, D., Cherubini, P., del Río, M., Cañellas, I. (2008): Growth response to climate and drought in Pinus nigra Arn. trees of different crown classes. - Trees 22: 363373.

[66] Márton, E., Fodor, L. (2003): Tertiary paleomagnetic results and structural analysis from the Transdanubian Range (Hungary): rotational disintegration of the Alcapa unit. Tectonophysics 363: 201-224.

[67] Mc Feeters, R. F., Chichester, C. O., Whitaker, J. R. (1971): Purification and properties of chlorophyllase from Ailanthus altissima (Tree-of-Heaven). - Plant Physiology 47: 609618.

[68] Mihály, B., Botta-Dukát, Z. (2004): Biológiai inváziók Magyarországon. Özönnövények. Biological invasions in Hungary. Invasive plants]. - Természetbúvár Alapítvány Kiadó, Budapest 407 p. [In Hungarian]

[69] Miller, J. H. (1990): Ailanthus altissima (Mill.) Swingle ailanthus. - Silvics of North America 2: 101-104.

[70] Moriondo, M., Good, P., Durao, R., Bindi, M., Giannakopoulos, C., Corte-Real, J. (2006): Potential impact of climate change on fire risk in the Mediterranean area. Climate Research 31: 85-95.

[71] Nearing, M. A., Pruski, F. F., O'neal, M. R. (2004): Expected climate change impacts on soil erosion rates: a review. - Journal of Soil and Water Conservation 59: 43-50.

[72] Németh, C. (2011): Bryofloristical data from the Transdanubian Mountain ranges, Bakony and Vértes Mts (Hungary). - Studia Botanica Hungarica 42: 5-22.

[73] Oxford Herbaria (2014): Fraxinus ornus (Fraxinus ornus). Ch. 6th, 88-108.

[74] http://herbaria.plants.ox.ac.uk/fraxigen/pdfs_and_docs/book/fraxigen_c6.pdf. Last accessed in 23052014

[75] Patterson, K. D. (2008): Vegetation classification and mapping at Petersburg National Battlefield, Virginia. - Technical Report NPS/NER/NRTR--2008/127. Philadelphia, PA: U.S. Department of the Interior, National Park Service, Northeast Region $235 \mathrm{p}$.

[76] Pan, E., Bassuk, N. (1985): Effects of soil type and compaction on the growth of Ailanthus altissima seedlings. - Journal of Environmental Horticulture 2: 13 
[77] Pieczka, I., Pongrácz, R., Bartholy, J. (2011): Comparison of Simulated Trends of Regional Climate Change in the Carpathian Basin for the 21st Century Using Three Different Emission Scenarios. - Acta Silvatica et Lignaria Hungarica 7: 9-22.

[78] Rabe, E. P. (1985): Distribution and growth response of Ailanthus altissima in the urban environment. - Ithaca, NY: Cornell University $87 \mathrm{p}$. Thesis.

[79] Robinson, G. R., Handel, S. N. (1993): Forest restoration on a closed landfill: rapid addition of new species by bird dispersal. - Conservation Biology 7: 271-278.

[80] Sander, D. H. (1963): Height-age curves for Pinus nigra in windbreaks on loess soils of Nebraska. - USDA Forest Service, Research Note RM-13. Rocky Mountain Forest and Range Experiment Station, Fort Collins, CO. 2 p.

[81] Sárospataki, M. (2014): Dendrológiai kertek a 19. századi magyarországi kertépítészetben Dendrological gardens in 19th century garden architecture in Hungary (Doctoral dissertation, Budapesti Corvinus Egyetem). http://phd.lib.unicorvinus.hu/753/1/Sarospataki_Mate.pdf. Last accessed in 23052014.

[82] Sheppard, S. R., Cizek, P. (2009): The ethics of Google Earth: Crossing thresholds from spatial data to landscape visualisation. - Journal of Environmental Management 90: 2102-2117.

[83] Shiu-ying, H. (1979): „Ailanthus altissima”. Arnoldia 39: 29-50.

[84] Soest, J., Ayral, P., Schober, R., Hummel, F. C. (1965): The standardization of symbols in forest mensuration. - University of Maine Agricultural Experiment Station, Technical Bulletin, Orono 15p.

[85] Strengers, B., Leemans, R., Eickhout, B., de Vries, B., Bouwman, L. (2004): The landuse projections and resulting emissions in the IPCC SRES scenarios as simulated by the IMAGE 2.2 model. - GeoJournal 61: 381-393.

[86] Thebaud, C., Debussche, M. (1991): Rapid invasion of Fraxinus ornus L. along the Herault River system in southern France: the importance of seed dispersal by water. Journal of Biogeography 18: 7-12.

[87] Török, K., Botta-Dukát, Z., Dancza, I., Németh, I., Kiss, J., Mihály, B., Magyar, D. (2003): Invasion gateways and corridors in the Carpathian Basin: biological invasions in Hungary. - Biological Invasions 5: 349-356.

[88] Trájer, A., Bede-Fazekas, Á., Hammer, T., Padisák, J. (2015): Modelling the growth of young individuals of Pinus nigra on thin carbonate soils under climate change in Hungary. - Acta Botanica Hungarica 57:419-442.

[89] Trifilò, P., Raimondo, F., Nardini, A., Gullo, M. L., Salle, S. (2004): Drought resistance of Ailanthus altissima: root hydraulics and water relations. - Tree Physiology 24: 107114.

[90] Udvardy, L. (1998a): Classification of adventives dangerous to the Hungarian natural flora. - Acta Botanica Hungarica 41: 315-331

[91] Udvardy, L. (1998b): Spreading and coenological circumstances of Ailanthus altissima (Ailanthus altissima) in Hungary. - Acta Botanica Hungarica 41: 299-314

[92] Váczi, B. (2011): A bálványfa (Ailanthus altissima) hatása az Aggteleki Nemzeti Park érintett társulásaira: http://dea.unideb.hu/dea/handle/2437/115179. Last accessed in 2305 2014 [In Hungarian]

[93] Van Haverbeke, D. F. (1990): Pinus nigra Arnold European Pinus nigra. In: Burns, Russell M.; \& Honkala, Barbara H., technical coordinators. - Silvics of North America. Volume 1. Conifers. Agric. Handb. 654.Washington, DC: U.S. Department of Agriculture, Forest Service 395-404.

[94] VassarStat: http://vassarstats.net/corr_big.html. Last accessed in 23052014

[95] Wang, J., Meng, J. J., Cai Y. L. (2008): Assessing vegetation dynamics impacted by climate change in the southwestern karst region of China with AVHRR NDVI and AVHRR NPP time-series. - Environmental Geology 54: 1185-1195. 
[96] Wimmer, R., Strumia, G., Holawe, F. (2000): Use of false rings in Pinus nigra to reconstruct early growing season precipitation. - Canadian Journal of Forest Research 30: 1691-1697.

[97] Winkler, D., Tóth, V. (2012): Effects of Afforestation with Pines on Collembola Diversity in the Limestone hills of Szárhalom (West Hungary). - Acta Silvatica et Lignaria Hungarica 8: 9-20.

[98] Zunya, W., Yihui, D., Jinhai, H., Jun ,Y. (2004): An updating analysis of the climate change in China in recent 50 years. - Acta Meteorologica Sinica 62: 228-236. 